\title{
Woody Plant Reestablishment in Modified Pinyon-Juniper Woodlands, New Mexico
}

KIETH E. SEVERSON

\section{Abstract}

Pinyon (Pinus edulis Engelm.), one-seed juniper (Juniperus monosperma (Engelm.) Sarg.), and alligator juniper (J. deppeana Steud.) woodlands in southwestern New Mexico were thinned, were pushed with bulldozers leaving slash in place, and were pushed and then slash piled and burned. There were no significant differences $(P>0.05)$ in densities of these trees 13 and 18 years later between untreated ( 379 trees/ha) and thinned ( 489 trees/ha) plots or between pushed/left (67 trees/ha) and pushed/piled/burned plots ( 49 trees/ha). Differences between bulldozed treatments and untreated/thinned treatments were significant $(P<0.05)$. Total shrubs, $75 \%$ of which were gray oak (Quercus grisea Liebm.) and hairy mountainmahogany (Cercocarpus breviflorus Gray), were significantly more abundant in untreated areas (672 shrubs/ha), than in any of the treatments. No differences were noted among treatments $(493,393,329$ shrubs/ha for thinned, pushed/left, and pushed/piled/burned, respectively). Rates of pinyon reestablishment increased slowly up to the mid-1960's (from 1.1 to 1.3 trees /ha/year) then accelerated to 10 to 13 trees/ha/year. Pinyon and juniper densities were about 120 trees/ha when reestablishment rates increased.

Pinyon-juniper woodlands occupy about 24.3 million hectares in the western United States (Short et al. 1977). These woodlands were generally restricted to sites with shallow, rocky soils. Over the last century, however, trees have become more dense on these sites and have invaded adjacent grasslands. Commonly suggested causes are: (1) overgrazing by livestock, (2) reduction in extent and frequency of fire, (3) increased dissemination of seeds, and (4) a change in weather or climatic conditions (Johnsen 1962, Arnold et al. 1964, Tausch et al. 1981). Not all pinyon-juniper woodlands have encroached onto adjacent types, however, despite the presence of one or more of the causative factors listed above (Johnsen 1962).

Pinyon-juniper woodlands are important livestock grazing areas. Efforts to control trees and shrubs to increase production of herbaceous forage have yielded variable results (Springfield 1976). Feasibility of pinyon-juniper control/eradication has been questioned as have existing hypotheses on site occupancy and successional status of pinyons and junipers (Lanner 1977).

Information on succession in pinyon-juniper stands following mechanical treatment or fire is available (Arnold et al. 1964, Barney and Frischknecht 1974, Tausch and Tueller 1977, Hessing et al. 1982, Rippel et al. 1983). However, these study sites either had been grazed by livestock or else grazing history was not defined. Arnold et al. (1964) examined effects of livestock grazing in pinyon-juniper stands but not in conjunction with control methods.

This study was conducted to evaluate response of trees and shrubs to 4 kinds of pinyon-juniper control, 13 to 18 years after treatment, in an area with little or no grazing by livestock, and to determine rates of change of woody plant densities over the same period based on pretreatment data. Such data may help clarify the role of livestock effects on pinyon-juniper succession.

\footnotetext{
Author is research wildlife biologist, USDA Forest Service, Rocky Mountain Forest and Range Experiment Station. Research was conducted at the Station's Research Work Unit in Tempe, Ariz., in cooperation with Arizona State University. Station headquarters is in Fort Collins, Colorado.

The author appreciates the assistance provided by personnel of the Gila National Forest throughout the study. Special thanks are given H. Dwain Smith, Mary Gilbert, and Gary Helbing for their help with data collection and analysis.

Manuscript accepted 27 January 1986.
}

\section{Study Area and Methods}

The study was conducted on the Fort Bayard Allotment, Gila National Forest, $16 \mathrm{~km}$ east of Silver City, New Mexico. Trees targeted for control were pinyon (Pinus edulis Engelm.), one-seed juniper (Juniperus monosperma (Engelm.) Sarg.), and alligator juniper (J. deppeana Steud.). Other important woody plants were gray oak (Quercus grisea Liebm.), hairy mountainmahogany (Cercocarpus breviflorus Gray), skunkbush sumac (Rhus trilobata Nutt.), and Wright silktassel (Garrya wrightii Torr.). Two-thirds of the perennial grass production was from blue grama (Bouteloua gracilis (H.B.K.) Steud.) and sideoats grama (B. curtipendula (Michx.) Torr.). Although more than 50 species of forbs have been collected, no single species dominated. Common genera included globemallow (Sphaeralcea spp.), goosefoot (Chenopodium spp.), and buckwheat (Eriogonum spp.) (Reynolds 1964, Short et al. 1977).

Upland soils were mostly Lithic and Lithic Vertic Haplustolls with intermingled smaller areas characterized by Cumulic Haplustolls and Ustalfic Argiustolls (Unpublished data, A.L. Medina, Rocky Mountain Forest and Range Experiment Station, Tempe, Arizona).

Study area elevation ranged from 1,806 to $2,070 \mathrm{~m}$. Annual precipitation was $393 \mathrm{~mm}, 55 \%$ falling as rain from July through September. Mean annual temperature was $128^{\circ} \mathrm{C}$, with mean monthly extremes of $3.5^{\circ} \mathrm{C}$ (January) and $22.6^{\circ} \mathrm{C}$ (July). Weather records are from the Fort Bayard State Hospital on the southern edge of the study area.

The study area, while part of the Fort Bayard Military Reservation, was heavily grazed by horses, mules, dairy cows, and beef cattle from 1869 to 1937. In 1937, all livestock were removed from the Reservation except for a few pack animals. In 1941, the entire 4,600 ha area was used as a horse training center and grazed by 30 to 120 horses. The training center was phased out beginning in 1963 , and horse use on the western half of the study area was eliminated by 1967 , about the time treatments were applied. Two pastures on the eastern half of the study area (Fig. 1) are still used as winter horse pastures. The pastures, 428 and 600 ha, are grazed by 30 to 40 horses and mules on alternate years from October to March. The Reservation is also included within the range of 90 to 120 elk (Cervus elaphus Erxleben), 100 mule deer (Odocoileus hemionus Rafinesque), and 75 white-tailed deer $(O$. virginianus Zimmerman). (Personal communication, G. Rickman, New Mexico Game and Fish, Silver City, New Mexico).

Five pinyon-juniper treatments, including an untreated check, were randomly established in 2 blocks in each of 2 years (Fig. 1). The lower 2 blocks, 1,880 to $1,935 \mathrm{~m}$, were treated in 1965 and the upper 2 blocks, 1,935 to $2,040 \mathrm{~m}$, in 1970 . Treatments included (1) thinned, where pinyons and junipers were cut to a minimum spacing of $6.1 \mathrm{~m}$ and left in place; (2) pushed/left, where all pinyons and junipers were pushed over with a bulldozer and were left in place; (3) pushed/piled/burned, where trees were pushed over and piled with a bulldozer, then burned; (4) partial removal, where pinyons and junipers were pushed and left, except on northeastern slopes greater than $15 \%$, where nothing was done; and (5) a check, where trees were not disturbed. Each treated area was approximately 120 ha. The partial removal treatments were not included in this study, because they were a combination of 2 other treatments-pushed/left and untreated.

Density of shrubs and trees was estimated by counting the number of individual plants on 5-m $\times 25-\mathrm{m}$ randomly placed plots. 

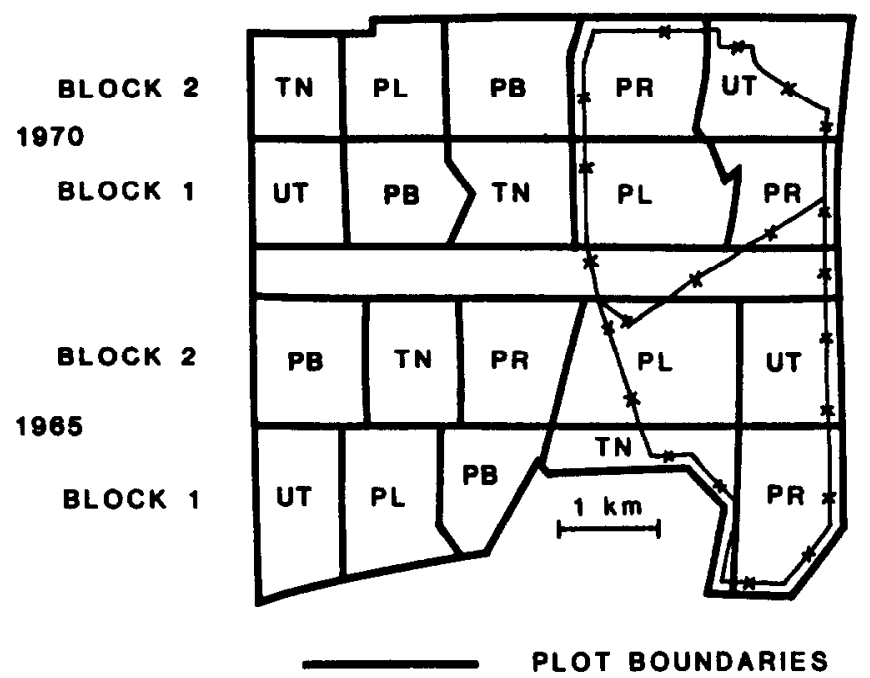

$\longrightarrow$ PASTURE FENCE

Fig. 1. Diagram of pinyon-juniper treatments, Fort Bayard, New Mexico. Area ungrazed by livestock except 2 pastures on the right receive light, alternate winter, horse use. Treatments are: $U T=$ untreated, $T N=$ thinned, $P L=$ pushed $/$ left,$P B=p u s h e d / p i l e d /$ burned, and $P R=$ partial removal.

Stein's two-stage test (Steel and Torrie 1980) was used to estimate the number of sampling plots needed per treatment. Heights of all plants in sample plots were measured. Density and height data were analyzed with a three-factor analysis of variance (time of treatment, blocks, and treatment) with unequal observations per cell to test the null hypothesis that there was no difference in density or height of species or species groups among treatments. Mean separation was by Student-Newman-Kuhls test (SAS Institute 1982). All statistical inferences were made at the 0.05 probability level.

An estimate of the year of establishment was obtained by dating trees from untreated, pushed/left, and pushed/piled/burned treatments in block 1, 1970 plots (Fig. 1). Preliminary analysis revealed that pinyon was the only species in the study area for which annual rings could be identified with confidence (Personal communication, Thomas Harlan, Laboratory of Tree-Ring Research, University of Arizona, Tucson). A belt transect, $5 \mathrm{~m}$ wide, was randomly established (both location and direction), and the first 10 pinyons encountered which were more than $0.3 \mathrm{~m}$ high were cut as close to ground level as possible, and a cross section was obtained. Five such transects were done on each treatment for a total of 50 tree cross sections per treatment. Establishment dates were determined by the Laboratory of Tree-Ring Research, University of Arizona, Tucson.

\section{Results and Discussion}

\section{Pinyon-Juniper Densities}

There were no differences in densities between ages of treatment, except for pinyon, which was more abundant in the youngest sets of treatments (1970). Reynolds (1964) and Short et al. (1977) both noted pinyon to be more abundant with increasing elevation; therefore, the difference probably is due to elevation rather than age of treatment. Because this was the only difference, year of treatment and block data were pooled in Table 1. Densities of total pinyons and junipers and of total junipers were significantly greater on untreated and thinned areas than on pushed/left and pushed/piled/burned, but no differences were detected between either treatment within these 2 groups (Table 1). Individual species responded differently, however; one-seed juniper and pinyon were significantly more abundant on the thinned treatment than on untreated plots, whereas alligator juniper was more numerous on treated areas than on thinned. Pinyon and one-seed juniper reinvade treated areas faster than alligator juniper, which agrees with the findings of Rippel et al. (1983).

Reasons for higher densities of pinyons and one-seed junipers in thinned plots are less obvious. Ideal seeding conditions may have been created by thinning. Pinyon and one-seed juniper require moist, shady conditions and the absence of a competing herbaceous layer for seedling development (Johnsen 1962, Fowells 1965). The thinning treatment imposed was not drastic enough to permit an understory response; the herbaceous standing crop was similar to that on untreated plots as noted by Short et al. (1977). Slash left by felling also provided sheltered sites for seedling establishment. Pinyon reinvasion of thinned areas was more evident on upper elevation plots, perhaps because of slightly better moisture conditions.

Numbers of pinyons and junipers on the pushed/left and pushed/piled/burned treatments were only $18 \%$ and $13 \%$, respectively, of the density on untreated plots (Table 1). This proportion is further reduced when the trees missed by bulldozers are accounted for. Ring counts indicated that $60 \%$ and $66 \%$ of all pinyons taller than $0.3 \mathrm{~m}$ on the pushed/left and pushed/piled/burned treatments, respectively, in 1983 were established before the 1970 treatment.

Assuming the same miss rate for juniper, and using 1983 density data for pinyon and juniper in the upper 2 blocks (Table 2), but excluding those up to $0.3 \mathrm{~m}$ tall (Table 3), an estimated 36 and 26 trees/ha were missed by the bulldozers in the pushed/left and pushed/piled/burned treatments, respectively. Therefore, an average of 47 and 26 trees/ha have become reestablished since 1970 , including those up to $0.3 \mathrm{~m}$ tall (based on the assumption that trees

Table 1. Denaity (stems/ha) of trees and shrubs on four pinyon-juniper treatments, Fort Bayard, New Mexico. 1983. Numbers are means \pm standard deviations of both 1965 and 1970 treatments.

\begin{tabular}{|c|c|c|c|c|}
\hline & Untreated & Thinned & Pushed/left & Pushed/piled/burned \\
\hline $\begin{array}{l}\text { One-seed juniper } \\
\text { Alligator juniper } \\
\text { Total junipers }\end{array}$ & $\begin{array}{c}63 \pm 19 \mathrm{a}^{1} \\
85 \pm 77 \mathrm{a} \\
148 \pm 61 \mathrm{a}\end{array}$ & $\begin{array}{rl}104 \pm 27 & b \\
38 \pm 48 & b \\
142 \pm 34 & a\end{array}$ & $\begin{array}{rl}31 \pm 27 & c \\
5 \pm 6 & c \\
34 \pm 28 & b\end{array}$ & $\begin{array}{r}10 \pm 2 d \\
3 \pm 3 \mathrm{c} \\
13 \pm 4 \mathrm{~b}\end{array}$ \\
\hline $\begin{array}{l}\text { Pinyon } \\
\text { Pinyon and juniper } \\
\text { Gray oak } \\
\text { Hairy mountainmahogany } \\
\text { Skunkbush sumac } \\
\text { Wright's silktassel } \\
\quad \text { Total shrubs } \\
\quad \text { Total species }\end{array}$ & $\begin{array}{r}231 \pm 96 \mathrm{a} \\
379 \pm 120 \mathrm{a} \\
337 \pm 56 \mathrm{a} \\
163 \pm 107 \mathrm{a} \\
137 \pm 48 \mathrm{a} \\
35 \pm 43 \mathrm{a} \\
672 \pm 207 \mathrm{a} \\
1,050 \pm 212 \mathrm{a}\end{array}$ & $\begin{array}{l}347 \pm 388 \mathrm{~b} \\
489 \pm 414 \mathrm{a} \\
192 \pm 86 \mathrm{~b} \\
190 \pm 97 \mathrm{a} \\
100 \pm 75 \mathrm{ab} \\
12 \pm 99 \mathrm{~b} \\
493 \pm 155 \mathrm{~b} \\
982 \pm 527 \mathrm{a}\end{array}$ & $\begin{array}{r}32 \pm 10 \mathrm{c} \\
67 \pm 31 \mathrm{~b} \\
156 \pm 63 \mathrm{~b} \\
102 \pm 91 \mathrm{~b} \\
121 \pm 72 \mathrm{ab} \\
14 \pm 14 \mathrm{~b} \\
393 \pm 102 \mathrm{c} \\
459 \pm 106 \mathrm{~b}\end{array}$ & $\begin{array}{r}37 \pm 10 \mathrm{c} \\
49 \pm 10 \mathrm{~b} \\
160 \pm 50 \mathrm{~b} \\
81 \pm 49 \mathrm{~b} \\
85 \pm 72 \mathrm{~b} \\
4 \pm 4 \mathrm{~b} \\
329 \pm 74 \mathrm{c} \\
378 \pm 77 \mathrm{~b}\end{array}$ \\
\hline
\end{tabular}

'Means within rows followed by same letter are not significantly different $(P>0.05)$. 
Table 2. Densities (stems/ha) of trees and shrubs on four pinyon-juniper treatments in 1966, 1974, and 1983, Fort Bayard, New Mexico. Numbers are means \pm standard deviations for the upper two blocks only treated in 1970.

\begin{tabular}{|c|c|c|c|}
\hline & $1966^{1}$ & 19741 & 1983 \\
\hline \multirow{5}{*}{$\begin{array}{l}\text { Untreated } \\
\text { Thinned } \\
\text { Pushed-left } \\
\text { Pushed-cleaned }\end{array}$} & \multirow{5}{*}{$\begin{array}{l}66 \pm 37 \\
70 \pm 40 \\
73 \pm 28 \\
91 \pm 30\end{array}$} & -Pinyon- & \\
\hline & & $169 \pm 34$ & $296 \pm 88$ \\
\hline & & $189 \pm 222$ & $523 \pm 567$ \\
\hline & & $30 \pm 3$ & $39 \pm 2$ \\
\hline & & $12 \pm 7$ & $31 \pm 2$ \\
\hline \multirow{5}{*}{$\begin{array}{l}\text { Untreated } \\
\text { Thinned } \\
\text { Pushed-left } \\
\text { Pushed-cleaned }\end{array}$} & \multicolumn{3}{|c|}{ 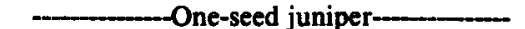 } \\
\hline & \multirow{4}{*}{$\begin{array}{l}15 \pm 4 \\
19 \pm 16 \\
30 \pm 28 \\
68 \pm 74\end{array}$} & $28 \pm 2$ & $61 \pm 11$ \\
\hline & & $18 \pm 1$ & $86 \pm 15$ \\
\hline & & $6 \pm 9$ & $25 \pm 9$ \\
\hline & & $3 \pm 3$ & $10 \pm 2$ \\
\hline \multirow{5}{*}{$\begin{array}{l}\text { Untreated } \\
\text { Thinned } \\
\text { Pushed-left } \\
\text { Pushed-cleaned }\end{array}$} & \multirow{5}{*}{$\begin{array}{l}39 \pm 8 \\
27 \pm 15 \\
37 \pm 8 \\
37 \pm 12\end{array}$} & ligator jun & \\
\hline & & $68 \pm 5$ & $111 \pm 38$ \\
\hline & & $44 \pm 34$ & $65 \pm 26$ \\
\hline & & $8 \pm 7$ & $7 \pm 7$ \\
\hline & & $4 \pm 1$ & $4 \pm 4$ \\
\hline & \multirow{5}{*}{$\begin{array}{r}143 \pm 89 \\
107 \pm 106 \\
90 \pm 6 \\
69 \pm 13\end{array}$} & Gray oak- & \\
\hline \multirow{5}{*}{$\begin{array}{l}\text { Untreated } \\
\text { Thinned } \\
\text { Pushed-left } \\
\text { Pushed-cleaned }\end{array}$} & & $232 \pm 93$ & \multirow{4}{*}{$\begin{array}{l}340 \pm 65 \\
241 \pm 111 \\
154 \pm 62 \\
129 \pm 36\end{array}$} \\
\hline & & $191 \pm 190$ & \\
\hline & & $136 \pm 26$ & \\
\hline & & $79 \pm 1$ & \\
\hline & \multicolumn{3}{|c|}{ Hairy mountainmahogany } \\
\hline \multirow{4}{*}{$\begin{array}{l}\text { Untreated } \\
\text { Thinned } \\
\text { Pushed-left } \\
\text { Pushed-cleaned }\end{array}$} & $132 \pm 55$ & $164 \pm 73$ & $225 \pm 64$ \\
\hline & $79 \pm 69$ & $113 \pm 107$ & $179 \pm 148$ \\
\hline & $95 \pm 32$ & $91 \pm 42$ & $145 \pm 132$ \\
\hline & $99 \pm 49$ & $92 \pm 70$ & $108 \pm 48$ \\
\hline
\end{tabular}

'From Short et al. (1977).

in this size range were established since 1970).

Reestablishment rates of pinyons and junipers will vary depending on method and effectiveness of treatment. Pinyon and juniper density on 20-year-old cabled areas in New Mexico was $79 \%$ of that on untreated areas (Rippel et al. 1983). Tausch and Tueller (1977), in Nevada, found the numbers of trees on chained areas up to 12 years old to be $58 \%$ of that on untreated areas. Fire appears to be more effective. Juniper and pinyon did not begin to reestablish areas burned by wildfires for 10 to 11 years and did not dominate until 46 to 71 years after burning (Barney and Frischknecht 1974). Hessing et al. (1982) did not find any pinyons or junipers in an Arizona powerline corridor bulldozed 5 years earlier.

\section{Pinyon-Juniper Heights}

All 3 target species were significantly taller on untreated and thinned treatments than on either pushed treatment (Table 4). There were no height differences between untreated and thinned areas or between the 2 pushed treatments. One-seed juniper and pinyon averaged about the same size on untreated and thinned areas, while alligator junipers were twice as tall as these species on both treatments. Mean height of all 3 species was about the same on the 2 pushed treatments.

Proportions of trees in different size classes varied according to treatment. All juniper species had a substantially large proportion of small seedlings/saplings ( $0.3 \mathrm{~m}$ or less) on untreated areas (Table 3), a trend also noted for pinyon on thinned plots. Pinyon and one-seed juniper had relatively smaller proportions in the same size range in both pushed treatments.

\section{Pinyon-Juniper Expansion and Reestablishment Rates}

Untreated or check plots are often assumed to be static where pretreatment data are not available. This is not a valid assumption. The untreated plots on the Fort Bayard Allotment were not stable; they were changing at faster rates than were the pushed plots, at least relative to pinyon-juniper densities. Pretreatment data for blocks established in 1965 were not available; however, Short et al. (1977) reported densities of trees and shrubs in 1966 and 1974 on the upper 2 blocks (treated in 1970) used in this study. Examination of these and 1983 data from the same blocks revealed that pinyon in untreated areas has been increasing at a steady rate (rate determined by dividing total increase in density by years in interval, Table 2): 13 trees/ha/year from 1966 to 1974 and 14 trees/ha/year from 1974 to 1983. One-seed juniper rates, while less ( 5 and 8 tree/ha/year) over the respective time periods, has been reasonably consistent.

Examination of dates that pinyons were established in the upper 2 blocks reveals that only a few trees established in the late 1800's

Table 3. Percentages of total individuals of each species $0.3 \mathrm{~m}$ or less tall in all blocks and upper two blocks on four pinyon-Juniper conversion treatments, Fort Bayard, New Mexico, 1983.

\begin{tabular}{|c|c|c|c|c|c|c|c|c|}
\hline & \multicolumn{4}{|c|}{ All blocks } & \multicolumn{4}{|c|}{ Upper two blocks } \\
\hline & UT $^{\mathbf{1}}$ & TN & $\mathbf{P L}$ & PB & $\mathbf{U T}$ & TN & $\mathbf{P L}$ & PB \\
\hline $\begin{array}{l}\text { Pinyon } \\
\text { One-seed juniper } \\
\text { Alligator juniper } \\
\text { Gray oak } \\
\text { Hairy mountainmahogany } \\
\text { Skunkbush sumac } \\
\text { Wright's silktassel }\end{array}$ & $\begin{array}{r}28.8 \\
19.7 \\
22.4 \\
20.0 \\
8.7 \\
4.2 \\
1.7\end{array}$ & $\begin{array}{r}29.8 \\
10.9 \\
4.4 \\
16.4 \\
7.7 \\
7.7 \\
4.6 \\
6.8\end{array}$ & $\begin{array}{l}11.9 \\
13.0 \\
12 \\
3.9 \\
2.1 \\
3.7 \\
0.0\end{array}$ & $\begin{array}{c}12.1 \\
6.3 \\
* \\
6.5 \\
2.5 \\
1.7 \\
0.0\end{array}$ & \begin{tabular}{c|}
34.4 \\
28.6 \\
33.8 \\
23.7 \\
12.2 \\
4.8 \\
$*$
\end{tabular} & $\begin{array}{r}36.1 \\
7.1 \\
5.3 \\
6.1 \\
8.1 \\
8.2 \\
*\end{array}$ & $\begin{array}{l}20.0 \\
10.5 \\
* \\
5.2 \\
2.0 \\
3.9 \\
*\end{array}$ & $\begin{array}{c}12.5 \\
20.0 \\
* \\
4.6 \\
2.9 \\
3.1 \\
*\end{array}$ \\
\hline
\end{tabular}

IUT = untreated, TN = thinned, PL = pushed $/$ left, $P B=$ pushed $/$ piled $/$ burned.

2*Indicates inadequate sample size.

Table 4. Heights (meters \pm standard deviations) of trees and shrubs on four pinyon-juniper treatments, Fort Bayard, New Mexico, 1983.

\begin{tabular}{|c|c|c|c|c|}
\hline & Untreated & Thinned & Pushed/left & Pushed/piled/burned \\
\hline $\begin{array}{l}\text { One-seed juniper } \\
\text { Alligator juniper } \\
\text { Pinyon } \\
\text { Gray oak } \\
\text { Skunkbush sumac } \\
\text { Hairy mountainmahogany }\end{array}$ & $\begin{array}{l}2.0 \pm 0.3 \mathrm{a}^{1} \\
3.5 \pm 0.6 \mathrm{a} \\
2.0 \pm 0.7 \mathrm{a} \\
1.6 \pm 0.2 \mathrm{a} \\
1.2 \pm 0.1 \mathrm{a} \\
1.5 \pm 0.3 \mathrm{a}\end{array}$ & $\begin{array}{l}2.0 \pm 0.4 \mathrm{a} \\
4.1 \pm 0.7 \mathrm{a} \\
1.7 \pm 0.2 \mathrm{a} \\
1.5 \pm 0.3 \mathrm{a} \\
1.3 \pm 0.5 \mathrm{a} \\
1.6 \pm 0.2 \mathrm{a}\end{array}$ & $\begin{array}{l}1.0 \pm 0.1 \mathrm{~b} \\
1.3 \pm 1.0 \mathrm{~b} \\
1.1 \pm 0.3 \mathrm{~b} \\
1.6 \pm 0.3 \mathrm{a} \\
1.1 \pm 0.1 \mathrm{a} \\
1.7 \pm 0.2 \mathrm{a}\end{array}$ & $\begin{array}{l}1.0 \pm 0.3 \mathrm{~b} \\
0.9 \pm 0.2 \mathrm{~b} \\
1.1 \pm 0.2 \mathrm{~b} \\
1.6 \pm 0.3 \mathrm{a} \\
1.1 \pm 0.2 \mathrm{a} \\
1.7 \pm 0.3 \mathrm{a}\end{array}$ \\
\hline
\end{tabular}

'Means within rows followed by same letter are not significantly different $(P>0.05)$. 
and early 1900 's are still alive. The oldest pinyon dated was established in 1880 . Before and during this period, trees had been cut for fuel, either by miners working the nearby Santa Rita copper mines, or by soldiers from Fort Bayard. Pictorial evidence for this time period from Fort Bayard and from USDA Forest Service photos (on file, Silver City District, Gila National Forest, Silver City, New Mexico) taken in the same area in the early 1900's shows only scattered trees and shrubs growing on the surrounding hillsides.

Percentages (from annual ring counts of pinyons in untreated plots of the upper 2 blocks) of trees present in 1983 that were established in the indicated time interval are: 1880-1900, 10.7\%; $1901-1936,23.2 \%$; 1937-1955, 12.5; 1956-1965, 10.7\%; and 1966$1983,42.9 \%$. Total trees per hectare established in each period, determined by using mean pinyon density in upper blocks (296, Table 2), deducting those 0.3 or less high (34.4\%, Table 3 ), and allocating the total to the above percentages, was $21,45,24,21,185$ for each respective time period. Note that those up to $0.3 \mathrm{~m}$ tall were added back into the 1966-1983 time interval, assuming that they were established during this period.

From 1880 through 1936, the mean number of pinyons becoming established on the study area each year and surviving until 1983 ranged from 1.1 to 1.3 trees/ha. During this period, trees were cut for firewood and the area was heavily grazed. Livestock grazing was reduced in 1937, and for the next 28 years, the mean rate of pinyon increase remained the same, 1.3 trees/ha/year. Presumably grazing reductions resulted in increased herbage growth which competed with pinyon seedlings. About 1955, and continuing for the next 11 years, up to Short's et al. (1977) first data collection, the mean rate increased to 2.3 trees/ha/year. Although grazing was light to none during this period, the total canopy influence may have begun to reach the point where it retarded herbaceous growth and enhanced conditions for pinyon seed germination and growth. The accelerated rate from 1966 to 1983 to 10.3 trees/ha/year may reflect the increasing dominance of the overstory.

Although some of the trees established during the 1966 to 1983 period will not survive because of natural mortality from insects, disease, competition, etc., there is other evidence that pinyon density is increasing rapidly on untreated plots. First, the large percentage of total individuals in the smallest size range (Table 3) indicates an increasing population. Second, total pinyon density on untreated plots has increased 4.5 times from 1966 to 1983 (Table 2). Third, the mean rate of pinyon increase on untreated plots was 13 trees/ha/year from 1966 to 1974 , only slightly less than the mean rate of increase 14 trees/ha/year from 1974 to 1983 (Table 2). Further, the rate for the interval 1966 to 1983 calculated by determining year of establishment (10 trees/ha/year) was comparable to the rate determined by using 1966 and 1983 pinyon densities (14 trees/ha/year) (Table 2).

The pushed/left and pushed/piled/burned plots treated in 1970 now have total pinyon-juniper densities of 71 and 45 trees/ha, respectively; but, as previously discussed, only 47 and 36 were established since 1970 (rates of 4 and 3 trees/ha/year over the 13-year period). Comparable rates of increase calculated from 1974 and 1983 densities (Table 2) were 3 and 2 trees/ha/year for this 9-year period.

Total pinyon and juniper density on untreated plots in 1966 was 120 trees/ha (Table 2). Rates of reestablishment apparently increased gradually until densities reached this level. A stocking level of 120 trees/ha appears to be the point at which reestablishment rates accelerate on this site.

Using total 1983 densities of 71 and 45 trees/ha on the pushed/left and pushed/piled/burned treatments, respectively, and reestablishment rates of 3 and 2 trees/ha/year, an estimated 16 and 33 more years will elapse before reestablishment in the respective treatments will accelerate to the current rate in untreated plots.

\section{Non-target Shrub Densities and Heights}

Gray oak, the most numerous broadleaf shrub/small tree on the study area was significantly more abundant on untreated areas than on any treated areas (Table 1). There were no significant differences among the 3 treatments. Wright's silktassel, the least abundant of the 4 shrubs studied, followed a similar trend. Hairy mountainmahogany was significantly more dense on untreated and thinned areas than on either pushed treatment. Skunkbush sumac, a shrub reported to increase with cabling (Rippel et al. 1983), did not respond to pushing or thinning (Table 1).

Reynolds (1964) noted that these shrubs increased with increasing tree density; but when densities exceeded 373 to 494 trees/ha the number of shrubs decreased. This study supports his conclusion. Untreated plots with mean pinyon and juniper densities of 379 trees/ha also contain 672 shrubs/ha while the slightly more dense thinned areas with 489 pinyons and junipers per hectare contain 493 shrubs/ ha (Table 1). There are also indicators that development of shrub stands is slowing on untreated plots. While gray oaks in the smallest size range are common, other shrubs are represented by a relatively small proportion of individuals of this size range (Table 3). In both pushed treatments, which have lowest shrub densities (Table 1), relatively few individuals of any shrub species are found in the smallest size range (Table 3 ).

Density increases have been reasonably consistent within treatments from 1966 to 1983 for gray oak and hairy mountainmahogany, the only shrubs for which data are available for all 3 periods (Table 2). Rates of gray oak increase were generally greater on untreated (12 trees/ha/year) and thinned plots ( 8 trees/ha/year) than on pushed plots ( 4 and 4 trees/ha/year). Mountainmahogany rates, while lower, indicate a similar trend $(6,6,3$, and 1 tree/ha/year on untreated, thinned, pushed, left, and pushed/piled/burned treatments, respectively). While bulldozing may have inadvertently damaged some shrubs, rates still indicate reduced recruitment on pushed plots.

There were no significant differences in heights of shrubs among treatments (Table 4), indicating that while increased tree density may favor shrub establishment, it has no apparent effect on height growth.

\section{Conclusions}

Data indicate an initial slow rate of pinyon-juniper reestablishment, both historically after all trees were removed by fuelwood cutters in the late-1800's and more recently on plots in which almost all pinyons and junipers were removed by bulldozers. In the first case, however, the rate apparently increased when pinyon and juniper tree density reached a level of about 120 trees/ha. The increase in pinyon and juniper establishment at this point was likely a result of repression of competing herbaceous growth by the developing canopy and creation of moist, shady litter accumulations needed for pinyon and juniper seedlings. Tall shrubs, which are increasing, would also enhance conditions for seedlings.

The expected time between treatment and the point of accelerating reestablishment probably varies with treatment. The pushed/left treatment had more trees missed ( 36 trees/ ha) by bulldozers. Slash and litter resulted in better seedbed conditions because the rate (4 trees/ha/year) was higher. Pushed/piled/burned treatments were more effective, leaving 26 trees/ha, and pinyon-juniper numbers increased at a slower rate ( 2 trees/ha/year).

Thinning pinyon-juniper stands to levels described in this study did not result in an understory response but did create conditions apparently ideal for pinyon-juniper regeneration, especially at higher elevations of the study area.

None of the pinyon-juniper treatments resulted in increased browse plant establishment or height growth. Shrub densities were greatest on untreated plots, and were maximum when tree densities were from about 370 to $\mathbf{4 5 0}$ trees/ha, a range approximated by Reynolds (1964) and slightly modified by data from this study.

Reestablishment rates described here are probably minimum because grazing by large ungulates was light to nearly absent. Additional grazing would likely increase rates of invasion, the amount depending on the intensity, frequency, and season of her- 
bage defoliation. Grazing reduces competition from the herbaceous understory; and reduction of competition, in turn, accelerates invasion (Johnsen 1962). What is unique is that grazing, while potentially a major influence in the earlier stages of reestablishment, assumes secondary status in the mid- to later stages, when pinyon and juniper numbers reach a certain density, which approximated 120 trees/ha on the site and conditions described here. At this point, rates may accelerate even without grazing. This was illustrated by a mean rate of increase of 20 pinyon and juniper trees/ha/year on untreated plots over a 17-year period (1966-1983).

The point at which reestablishment rates accelerate probably depends on local site conditions. Knowing what this point is and what the rates are before and after this point is reached, would help to manage a stand. Also, information about the range of pinyonjuniper stocking levels that result in maximum browse and/or mast availability would facilitate stand management whether goals are forage for livestock, cover and forage for wildlife, wood for fuel, or a combination thereof.

\section{Literature Cited}

Amold, J.F., D.A. Jameson, and E.H. Reid. 1964. The pinyon-juniper type of Arizona: Effects of grazing, fire, and tree control. USDA Prod. Res. Rep. No. 84.

Barney, M.A., and N.C. Friachknecht. 1974. Vegetation changes following fire in the pinyon-juniper type of west-central Utah. J. Range Manage. 27:91-96.

Fowells, H.A. 1965. Silvics of forest trees of the United States. USDA Forest Service, Agr. Handbook No. 271.
Hessing, M.B., C.D. Johnson, and R.P. Balda. 1982. Early secondary succession of a pinyon-juniper woodland in a northern Arizona powerline corridor. Southwest Natur. 27:1-9.

Johnsen, T.N., Jr. 1962. One-seed juniper invasion of northern Arizona grassland. Ecol. Monogr. 32:187-207.

Lanner, R.M. 1977. The eradication of pinyon-juniper woodlands. West. Wildl. Spring, 12-17.

Reynolds, H.G. 1964. Elk and deer habitat use of a pinyon-juniper woodland in southern New Mexico. Trans. North Amer. Wildl. Conf. 29:438-444.

Rippel, P.L., R.D. Pieper, and G.A. Lymbery. 1983. Vegetational evaluation of pinyon-juniper cabling in south-central New Mexico. J. Range Manage. 36:13-15.

SAS Intitute, Inc. 1982.SAS user's guide: Statistics. SAS Inst., Inc., Cary, N.C.

Short, H.L., W. Evans, and E.L. Boeker. 1977. The use of natural and modified pinyon pine-juniper woodlands by deer and elk. J. Wild. Manage. 41:543-559.

Springfield, H.W. 1976. Characteristics and management of southwestern pinyon-juniper ranges. The status-of-our knowledge. USDA Forest Serv. Res. Pap. RM-160.

Steel, R.G.D., and J.H. Torrie. 1980. Principles and procedures of statistics, 2nd ed. McGraw-Hill Book Co., N.Y.

Tausch, R.J., and P.T. Tueller. 1977. Plant succession following chaining of pinyon-juniper woodlands in eastern Nevada. J. Range Manage. 30:44-49.

Tausch, R.J., N.E. West, and A.A. Nabi. 1981. Tree age and dominance patterns in Great Basin pinyon-juniper woodlands. J. Range Manage. 34:259-264.

\title{
Range Research: Basic Problems and Techniques
}

\author{
editors: C. Wayne Cook and James Stubbendieck
}

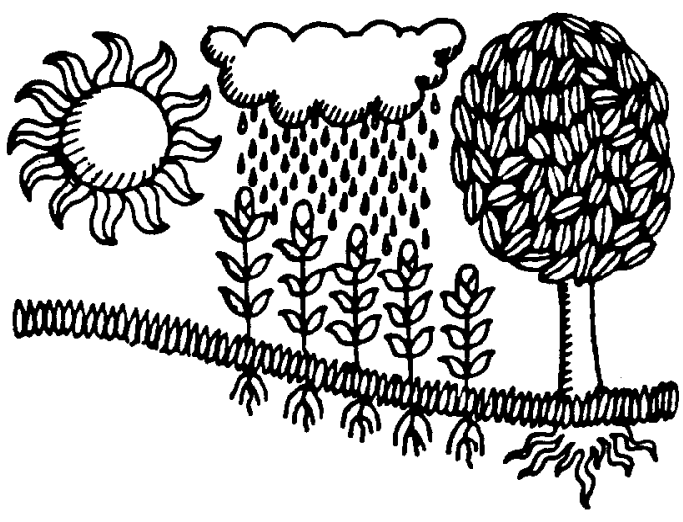

RANGE RESEARCH: BASIC PROBLEMS AND TECHNIQUES, a major revision of an earlier publication of the National Academy of Science, presents steps in research planning, evaluation of results, and methods and procedures in range research, including sampling techniques and experimental design. Chapter titles include: The Range Research Problem, Assessment of Habitat Factors, Methods of Studying Vegetation, Studies of Root Habits and Development, Methods of Measuring Herbage and Browse Utilization, Livestock Selection and Management in Range Research, Methods for Studying Rangeland Hydrology, Economic Research in Range Management, Sampling Methods with Special Reference to Range Management, Experimental Design, and Problems Involved in the Application of Research Techniques in Range Management. The book is designed to serve as a reference guide for range research methodology and as a textbook for advanced students who anticipate careers in this increasingly important field.

1986. 336 pages ISBN 09603692-3-6. \$28/hard.

Society for Range Management

2760 West Fifth Avenue, Denver, CO 80204 